\title{
Biofilm-producing ability of Staphylococcus aureus isolates from Brazilian dairy farms
}

\author{
S. H. I. Lee, ${ }^{\star}$ B. L. C. Mangolin, ${ }^{\star}$ J. L. Gonçalves,† D. V. Neeff, ${ }^{\star}$ M. P. Silva, ${ }^{\star}$ A. G. Cruz, $\ddagger$ and C. A. F. Oliveira* \\ *University of São Paulo, Faculty of Animal Science and Food Engineering, Department of Food Engineering, Av. Duque de Caxias Norte, 225, \\ CEP 13635-900 Pirassununga/São Paulo, Brazil \\ †University of São Paulo, School of Veterinary Medicine and Animal Science, Department of Nutrition and Animal Production, Pirassununga-SP, \\ 13635-900, Brazil \\ $\ddagger$ State University of Campinas, Faculty of Food Engineering, Department of Food Technology, \\ Caixa Postal 6121 CEP 13083-970 Campinas/São Paulo, Brazil
}

\begin{abstract}
This study aimed to investigate the in silico biofilm production ability of Staphylococcus aureus strains isolated from milking parlor environments on dairy farms from São Paulo, Brazil. The Staph. aureus isolates were obtained from 849 samples collected on dairy farms, as follows: milk from individual cows with subclinical mastitis or history of the disease $(\mathrm{n}=220)$; milk from bulk tank $(\mathrm{n}=120)$; surfaces of milking machines and utensils $(\mathrm{n}=389)$; and milk handlers $(\mathrm{n}=120)$. Thirty-one Staph. aureus isolates were obtained and categorized as pulsotypes by pulsed-field gel electrophoresis and submitted to assays for biofilm formation on polystyrene, stainless steel, rubber, and silicone surfaces. Fourteen $(45.2 \%)$ pulsotypes were considered producers of biofilm on the polystyrene microplate assay, whereas $13(41.9 \%)$ and $12(38.7 \%)$ pulsotypes were biofilm producers on stainless steel and rubber, respectively. None of the pulsotypes evaluated produced biofilms on silicone. Approximately $45 \%$ of Staph. aureus pulsotypes isolated from different sources on dairy farms showed the ability to produce biofilms in at least one assay, indicating possible persistence of this pathogen in the milking environment. The potential involvement of Staph. aureus in subclinical mastitis cases and its occurrence in milk for human consumption emphasize the need to improve hygiene practices to prevent biofilm formation on the farms studied.
\end{abstract}

Key words: Staphylococcus aureus, biofilm, milk, persistence

\section{INTRODUCTION}

Staphylococcus aureus is recognized worldwide as a frequent cause of subclinical IMI in dairy cows (Coelho

Received August 19, 2013.

Accepted December 2, 2013.

${ }^{1}$ Corresponding author: carlosaf@usp.br et al., 2011), and different sources of Staph. aureus in the dairy cow environment have been described (Zadoks et al., 2002). Intramammary infections in dairy cows are a major concern for the dairy industry, resulting in important loss of milk and suffering for the animals. They may also be potentially fatal, with major costs for dairy farmers. It is assumed that IMI are the result of cow-to-cow transmission, where infected animals in the herd, workers, and equipment and utensils used for milking are the main sources of the microorganism (De Vliegher et al., 2012).

Biofilms are structured communities of bacterial cells enclosed in a self-produced polymeric matrix and adhered to inert or living surfaces (Costerton et al., 1999). They are formed by adherence of the bacteria to the surface, followed by accumulation, maturation, and detachment, which are essential for dissemination and persistence of staphylococci (Fey and Olson, 2010). Biofilm formation is a potential virulence factor (Almeida and Oliver, 2001), especially for Staph. aureus; the ability to attach to surfaces has been demonstrated in the milk-processing environment, such as on rubber and stainless steel (Czechowski, 1990). These surfaces can be contaminated by spoilage or pathogenic bacteria that, under certain conditions, adhere to those surfaces, initiating cell growth and leading to biofilm formation (Fox et al., 2005). Thus, the present study aimed to evaluate the ability of Staph. aureus isolates obtained from milk and surfaces of the dairy environment to adhere to and produce biofilms on stainless steel, polystyrene, silicone, and rubber surfaces, as these materials are widely used in the milking environment as well in dairy plants.

\section{MATERIALS AND METHODS}

\section{Sampling Design and Isolation of Staphylococcus aureus}

Two hundred twenty samples of milk from individual cows (cows with subclinical mastitis or history of mas- 
titis), 120 samples of bulk tank milk, 389 swabs from milking machines and utensils (buckets and sieves), and 120 samples from workers' hands in 10 dairy farms located in the State of São Paulo, Brazil, were analyzed. The samples were collected monthly in the farms from August 2010 to January 2011. Samples were transported to the laboratory in coolers with ice $\left(5.0 \pm 1.2^{\circ} \mathrm{C}\right)$, and analyzed on the same day.

Staphylococcus aureus strains were detected and identified according to Lancette and Bennett (2001) by spread plates of Baird Parker agar with appropriate dilutions $(0.1 \mathrm{~mL})$, incubated at $35^{\circ} \mathrm{C}$ for $48 \mathrm{~h}$. Black colonies with 2 halos were considered presumptive of Staph. aureus. These presumptive strains were confirmed by Gram staining, catalase reaction, clotting of rabbit plasma, presence of clumping factor (Staphyclin test; Laborclin, Pinhais, Brazil), and acetoin production. After identification, the isolates were maintained at $-80^{\circ} \mathrm{C}$ until pulsotype determination by molecular typing using pulsed-field gel electrophoresis according to McDougal et al. (2003). Gels were analyzed using computer software (BioNumerics, version 6.1; Applied Maths Inc., Austin, TX) to define pulsotypes, as described by Lee et al. (2012).

\section{Biofilm Formation Assays}

The ability of the Staph. aureus pulsotypes to produce biofilms on flat-bottomed polystyrene microplates was determined according to the protocol described by Stepanović et al. (2000). Briefly, each pulsotype was resuspended in tubes containing tryptone soy broth (TSB; Oxoid Ltd., Basingstoke, UK), incubated at $37^{\circ} \mathrm{C}$ for $24 \mathrm{~h}$ and diluted until a concentration of $10^{8}$ cells/mL ( 0.5 on MacFarland scale) was reached. Triplicate aliquots of $200 \mu \mathrm{L}$ of each bacterial suspension were transferred to 3 wells of a sterile, 96-well, flatbottomed plastic microplate and incubated at $37^{\circ} \mathrm{C}$ for $24 \mathrm{~h}$. After incubation, the microplates were shaken, fixed, stained using crystal violet for $5 \mathrm{~min}$, dried, and resolubilized with $33 \%$ (vol/vol) glacial acetic acid. Biofilm formation in the microplates was measured in an ELISA reader set at $570 \mathrm{~nm}$, and values were expressed in optical density values (OD). Triplicate negative controls with only sterile TSB were prepared exactly as described for the pulsotypes (Stepanovic et al., 2000) and used as reference to determine the ability of Staph. aureus pulsotypes to produce biofilms. The mean $\mathrm{OD}$ value of negative controls $\left(\mathbf{O D}_{\mathrm{NC}}\right)$ was $0.160 \pm 0.021$. Pulsotypes were considered biofilm producers when their OD values were 3 times greater than standard deviation of the mean $\mathrm{OD}_{\mathrm{NC}}$. A positive control (Staphylococcus epidermidis ATCC 35.983) was also used. Additionally, pulsotypes showing ability to produce biofilms were classified as weak $\left(\mathrm{OD}_{\mathrm{NC}}<\mathrm{OD}\right.$ $\left.\leq 2 \times \mathrm{OD}_{\mathrm{NC}}\right)$, moderate $\left(2 \times \mathrm{OD}_{\mathrm{NC}}<\mathrm{OD} \leq 4 \times \mathrm{OD}_{\mathrm{NC}}\right)$ or strong $\left(\mathrm{OD}>4 \times \mathrm{OD}_{\mathrm{NC}}\right)$ biofilm producers, according to Stepanović et al. (2000).

The ability to produce biofilms on stainless steel, rubber, and silicone surfaces was evaluated by epifluorescence microscopy using calcofluor white dye, as recommended by Shanks et al. (2005). Two square pieces $(1.0 \times 1.0 \mathrm{~cm})$, one of stainless steel and one of rubber, and one silicone disc (diameter: $1.0 \mathrm{~cm}$ ) were placed at the bottom of 3 wells of a 96-well flat-bottomed plastic microplate. Next, $2 \mathrm{~mL}$ of each TSB bacterial suspension were placed in each of the 3 wells and incubated at $35^{\circ} \mathrm{C}$ for $48 \mathrm{~h}$ without stirring. After incubation, the stainless steel and rubber coupons and silicone discs were removed from the wells with sterile forceps, rinsed with sterile water, placed on a glass slide, and allowed to dry at room temperature. One drop of calcofluor solution $(0.05 \%, \mathrm{wt} / \mathrm{vol})$ was added to each of the surfaces. The visualization of biofilms on stainless steel, rubber, and silicone discs was performed in an optical epifluorescence microscope (Olympus, Tokyo, Japan), with the wavelength set at $430 \mathrm{~nm}$. Staphylococcus epidermidis (ATCC 35.983) and Staph. epidermidis (ATCC 12.228) strains were used as positive and negative controls, respectively, and served as the basis for image analysis using computer software (DP2-BSW, version 2.1; Olympus).

\section{RESULTS AND DISCUSSION}

Table 1 shows the ability of the 31 Staph. aureus pulsotypes to produce biofilms in the polystyrene microplate assays. Seventeen pulsotypes $(54.8 \%)$ did not produce biofilms, whereas $14(45.2 \%)$ pulsotypes were classified as weak $(\mathrm{n}=9)$, moderate $(\mathrm{n}=2)$, or strong $(\mathrm{n}=3)$ biofilm producers, respectively. Biofilm production is recognized as an important virulence factor for bacteria of the genus Staphylococcus (Cucarella et al., 2002; Vasudevan et al., 2003; Fox et al., 2005). Hence, formation of biofilms by Staph. aureus is a major concern for the dairy industry and is frequently associated with a lack of monitoring of operational standards established for processing milk (Zadoks et al., 2002). The high frequency of Staph. aureus biofilm-producing isolates highlights the need for constant improvement of quality assurance systems in the dairy farms evaluated.

Although we conducted no genetic evaluation in the present study, previous reports have shown that the IS257 gene is related to in vitro biofilm formation by Staph. aureus isolates from cows with mastitis, with $50 \%$ prevalence. Similarly, the ica gene cluster acts directly on the production of an extracellular adhesin polysaccharide, which is associated with pathogenic 
LEE ET AL.

Table 1. Biofilm formation by Staphylococcus aureus pulsotypes in the microplate assay ${ }^{1}$

\begin{tabular}{|c|c|c|}
\hline Category $^{2}$ & No. (\%) of pulsotypes & Optical density \\
\hline Biofilm nonproducers & $17(54.8)$ & $0.136 \pm 0.017$ \\
\hline \multicolumn{3}{|l|}{ Biofilm producers } \\
\hline Weak & $9(29.0)$ & $0.203 \pm 0.040$ \\
\hline Moderate & $2(6.5)$ & $0.420 \pm 0.039$ \\
\hline Strong & $3(9.7)$ & $0.695 \pm 0.104$ \\
\hline \multicolumn{3}{|c|}{$\begin{array}{l}{ }^{1} \mathrm{n}=31 \text { pulsotypes, as defined by pulsed-field gel electrophoresis; values are expressed as mean } \pm \text { SD of } 3 \\
\text { replicates of each pulsotype. }\end{array}$} \\
\hline \multicolumn{3}{|c|}{$\begin{array}{l}{ }^{2} \text { Classified by comparison of each pulsotype optical density (OD) with the mean OD value of negative con- } \\
\text { trols }\left(\mathrm{OD}_{\mathrm{NC}}=0.160 \pm 0.021\right) \text {, according to Stepanović et al. }(2000) \text {, as follows: nonproducers }\left(\mathrm{OD} \leq \mathrm{OD} \mathrm{N}_{\mathrm{NC}}\right) \text {, } \\
\text { weak }\left(\mathrm{OD}_{\mathrm{NC}}<\mathrm{OD} \leq 2 \times \mathrm{OD}_{\mathrm{NC}}\right) \text {, moderate }\left(2 \times \mathrm{OD}_{\mathrm{NC}}<\mathrm{OD} \leq 4 \times \mathrm{OD}_{\mathrm{NC}}\right) \text {, or strong }\left(\mathrm{OD}>4 \times \mathrm{OD}_{\mathrm{NC}}\right) \text { biofilm } \\
\text { producers. }\end{array}$} \\
\hline
\end{tabular}

Staph. aureus infections (Melchior et al., 2011). The ica gene was also present in Staph. aureus strains isolated from cows with mastitis in eastern Poland, showing a prevalence of $100 \%$ in all strains classified as biofilm producers (Szweda et al., 2012).

None of the Staph. aureus pulsotypes evaluated produced biofilm on silicone. Staphylococcus aureus pulsotypes isolated from different sources on dairy farms that showed ability to produce biofilms on microplates, stainless steel, and rubber are presented in Table 2 . Thirteen $(42.0 \%)$ pulsotypes were biofilm producers on stainless steel, and $12(38.7 \%)$ produced biofilms on rubber. Only pulsotype P21, derived from an isolate from bulk tank milk and an isolate from a milking machine, produced biofilms in the polystyrene microplate, stainless steel, and rubber assays. Approximately $42 \%$ of the pulsotypes obtained from bulk tank milk, milk from individual cows, and environmental samples were biofilm producers in the stainless steel and rubber assays. However, many Staph. aureus pulsotypes from bulk tank milk or milk from individual cows were biofilm producers in at least one assay. This fact is of public health concern because it indicates a potential source for persistence of Staph. aureus contamination on the dairy farms evaluated and emphasizes the difficulties in cleaning procedures of the milking equipment.

Possible explanations for the absence of biofilm formation on silicone, as observed in the present study, are difficult to assess at this time, because the initial adhesion of bacteria onto inert surfaces is a complex process resulting from physicochemical interactions between different components, including material surface properties, surface properties of bacteria, and environmental factors (An and Friedman, 1998; Oliveira et al., 2003). Silicone and stainless steel have similar hydrophobic characteristics (Ksontini et al., 2013); therefore, the Staph. aureus pulsotypes evaluated were expected to produce biofilm on both materials. Besides hydrophobicity and surface tension parameters, roughness of the material's surface is another factor that can influence bacterial adhesion to a given material (Katsikogianni et al., 2006). Rough surfaces, as found in rubber, have greater surface areas than smooth surfaces, such as in silicone, hence providing more favorable conditions for colonization (Baker and Greenham, 1988). However, the formation of biofilms on silicone surfaces has been reported for Staph. epidermidis (Sousa et al., 2009) and Bacillus cereus (Hamida et al., 2013). It remains to

Table 2. Staphylococcus aureus pulsotypes isolated from different sources in dairy farms and their ability to produce biofilms on microplates, stainless steel, or rubber ${ }^{1}$

\begin{tabular}{|c|c|c|c|}
\hline Source of isolates & $\begin{array}{l}\text { Microplate } \\
(\mathrm{n}=14)\end{array}$ & $\begin{array}{l}\text { Stainless steel } \\
(\mathrm{n}=13)\end{array}$ & $\begin{array}{l}\text { Rubber } \\
(\mathrm{n}=13)\end{array}$ \\
\hline BULK MILK & $\begin{array}{l}\mathrm{P} 01^{\mathrm{S}}, \mathrm{P} 15^{\mathrm{W}}, \mathrm{P} 23^{\mathrm{W}}, \\
\mathrm{P} 25^{\mathrm{W}}, \mathrm{P} 18^{\mathrm{W}}, \mathrm{P} 30^{\mathrm{W}}\end{array}$ & $\mathrm{P} 01, \mathrm{P} 12, \mathrm{P} 20, \mathrm{P} 23, \mathrm{P} 25$ & P13, P15, P30 \\
\hline Milk from individual cows & $\mathrm{P} 16^{\mathrm{S}}, \mathrm{P} 22^{\mathrm{M}}, \mathrm{P} 03^{\mathrm{W}}$ & $\mathrm{P} 03, \mathrm{P} 16$ & $\mathrm{P} 11, \mathrm{P} 22$, \\
\hline Milkers' hand and milking equipment ${ }^{2}$ & & P07 & \\
\hline Milking equipment $^{2}$ & $\mathrm{P} 02^{\mathrm{W}}, \mathrm{P} 24^{\mathrm{S}}, \mathrm{P} 08^{\mathrm{W}}$ & $\mathrm{P} 08, \mathrm{P} 28, \mathrm{P} 24$ & $\mathrm{P} 02, \mathrm{P} 08, \mathrm{P} 17, \mathrm{P} 28$ \\
\hline $\begin{array}{l}\text { Bulk milk, milk from individual cows, milkers' hands, } \\
\text { and milking equipment }\end{array}$ & - & P09 & - \\
\hline Milk from individual cows and bulk milk & $\mathrm{P} 29^{\mathrm{W}}$ & - & $\mathrm{P} 10$ \\
\hline Milkers' hands & - & - & P31 \\
\hline
\end{tabular}

${ }^{1}$ Defined by pulsed-field gel electrophoresis; $\mathrm{W}=$ weak; $\mathrm{M}=$ moderate; $\mathrm{S}=$ strong.

${ }^{2}$ Surfaces of milking machine (internal surface of teat cups) and utensils (sieves and buckets). 
be determined if variations in the surface properties of microorganisms could be involved in differences in the ability of Staph. aureus and other bacteria species to produce biofilm on silicone surfaces.

Comparison of data presented in our study with other previous reports is difficult because little information is available on biofilm formation by Staph. aureus isolates from dairy farms. Meira et al. (2012) observed that formation of biofilms by Staph. aureus isolates from the food industry in the same materials used in the present study was achieved after $3 \mathrm{~d}$ of cultivation. The authors also observed that peracetic acid $(30 \mathrm{mg} / \mathrm{L})$ and sodium hypochlorite $(250 \mathrm{mg} / \mathrm{L})$ were unable to remove the bacterial cells from the matrix of preformed biofilms, confirming that bacteria in biofilms are generally more resistant to environmental stress than their free-living counterparts (Costerton et al., 1999). In another study, carried out in 2 dairy factories producing UHT skim milk, the formation of biofilms by Staph. aureus occurred preferentially on polystyrene compared with stainless steel, suggesting that hydrophobicity was also a relevant factor in the formation of biofilms by Staph. aureus strains (Pagedar et al., 2010). However, no variation in biofilm formation by Staph. aureus pulsotypes on surfaces of polystyrene, stainless steel, or rubber was observed in the current study.

Even taking into consideration the limitations of this study in assessing adhesion, detachment, and biofilm formation of a monospecies inoculum under static conditions, our findings indicate that some of the Staph. aureus isolates assayed presented a clear ability to adhere and form biofilms on stainless steel, polystyrene, silicone, and rubber surfaces. This fact emphasizes the need for further studies for effective control of undesirable biofilms in the environment of dairy farms, including the type and nature of the contaminating residual materials (carbohydrates, fat, proteins, mineral salts) and how the natural mixed microbiota influences pathogen reduction during disinfection of surfaces (Simões et al., 2010). Integrated studies in regions that have dairy herds should include an initial investigation of the prevalence and identification of Staph. aureus strains with the ability to produce biofilms on materials commonly used in the dairy industry. In a second stage, different concentrations of sanitizers used in milk handling and processing lines should be evaluated, and predictive models should be generated to evaluate microbial growth parameters under the conditions in which these sanitizers are commonly used. Finally, the parameters obtained with application of these models should be evaluated to serve as an initial step to establish sanitizing procedures (Dias et al., 2012). These studies should be carried out on a regional basis using local dairy herds, because Staph. aureus strains found in the milking environments show considerable variability in relation to various parameters of growth and metabolic activity.

Taking into account the variations in the ability of Staph. aureus pulsotypes to produce biofilms in different materials, further investigations are needed to determine the presence or absence of known genes involved in biofilm formation, such as bap and ica (Szweda et al., 2012). This might help to explain why some materials are more prone to promote biofilm formation than others commonly used in equipment and utensils in dairy farms.

\section{CONCLUSIONS}

Almost $45 \%$ of Staph. aureus pulsotypes isolated from different sources on dairy farms had the ability to produce biofilms on microplates, stainless steel, or rubber, indicating possible persistence of this pathogen in the milking environment. However, none of the pulsotypes evaluated was able to produce biofilms on silicone. Given the potential involvement of Staph. aureus in subclinical mastitis cases and its occurrence in milk for human consumption, hygiene practices must be improved to prevent biofilm formation on the farms studied.

\section{ACKNOWLEDGMENTS}

The authors thank the Fundação de Amparo à Pesquisa do Estado de São Paulo (FAPESP, São Paulo, Brazil) for the scholarship, and thank Antonio A. M. Maia and Claudia L.V. Leal (both from the University of São Paulo, Department of Basic Sciences, Pirassununga, Brazil) and Carlos H. Camargo (State University of São Paulo, Department of Microbiology and Immunology, Botucatu, Brazil) for the assistance during the experiment.

\section{REFERENCES}

Almeida, R. A., and P. S. Oliver. 2001. Interaction of coagulase-negative Staphylococcus species with bovine mammary epithelial cells. Microb. Pathog. 31:205-212.

An, Y. H., and R. J. Friedman. 1998. Concise review of mechanisms of bacterial adhesion to biomaterial surfaces. J. Biomed. Mater. Res. 43:338-348.

Baker, A. S., and L. W. Greenham. 1988. Release of gentamicin from acrylic bone cement: Elution and diffusion studies. J. Bone Joint Surg. Am. 70:1551-1557.

Coelho, S. M., I. A. Pereira, L. C. Soares, B. R. Pribul, and M. M. Souza. 2011. Profile of virulence factors of Staphylococcus aureus isolated from subclinical bovine mastitis in the state of Rio de Janeiro, Brazil. J. Dairy Sci. 94:3305-3310.

Costerton, J. W., P. S. Stewart, and E. P. Greenberg. 1999. Bacterial biofilms: A common cause of persistent infections. Science 284:1318-1322.

Cucarella, C., M. A. Tormo, E. Knecht, B. Amorena, I. Lasa, T. J. Foster, and J. R. Penades. 2002. Expression of the biofilm-asso- 
ciated protein interferes with host protein receptors of Staphylococcus aureus and alters the infective process. Infect. Immun. 70:3180-3186.

Czechowski, M. H. 1990. Bacterial attachment to Buna-N gaskets in milk processing equipment. Aust. J. Dairy Technol. 45:113-114.

De Vliegher, S., L. K. Fox, S. Piepers, S. McDougall, and H. W. Barkema. 2012. Mastitis in dairy heifers: Nature of the disease, potential impact, prevention, and control. J. Dairy Sci. 95:1025-1040.

Dias, M. A. C., A. S. Sant'Ana, A. G. Cruz, J. A. F. Faria, C. A F. Oliveira, and E. Bona. 2012. On the implementation of good manufacturing practices in a small processing unity of mozzarella cheese in Brazil. Food Contr. 24:199-205.

Fey, P. D., and M. E. Olson. 2010. Current concepts in biofilm formation of Staphylococcus epidermidis. Future Microbiol. 5:917-933.

Fox, L. K., R. N. Zadoks, and C. T. Gaskins. 2005. Biofilm production by Staphylococcus aureus associated with intramammary infection. Vet. Microbiol. 107:295-299.

Hamida, K., K. Faten, E. A. Soumya, I. K. Saad, L. Hassan, and H Moktar. 2013. Bacillus cereus adhesion: An investigation of the physicochemical characteristics of surface and effect of bioadhesion on the properties of silicone. J. Adhes. Sci. Technol. 27:90-101.

Katsikogianni, M., I. Spiliopoulou, D. P. Dowling, and Y. F. Missirlis. 2006. Adhesion of slime producing Staphylococcus epidermidis strains to PVC and diamond-like carbon/silver/fluorinated coatings. J. Mater. Sci. Mater. Med. 17:679-689.

Ksontini, H., F. Kachouria, S. El Abed, S. I. Koraichi, H. Meftah, H. Latrache, and H. Moktar. 2013. Dairy biofilm: An investigation of the impact on the surface chemistry of two materials: Silicone and stainless steel. J. Adhes. Sci. Technol. 27:783-793.

Lancette, G. A., and R. W. Bennett. 2001. Staphylococcus aureus and staphylococcal enterotoxins. Pages 387-403, in Compendium of Methods for the Microbiological Examination of Foods. F. P. Downes and K. Ito, ed. American Public Health Association, Washington, DC.

Lee, S. H. I., C. H. Camargo, J. L. Gonçalves, A. G. Cruz, B. T. Sartori, M. B. Machado, and C. A. F. Oliveira. 2012. Characterization of Staphylococcus aureus isolates in milk and the milking environment from small-scale dairy farms of São Paulo, Brazil, using pulsed-field gel electrophoresis. J. Dairy Sci. 95:7377-7383.

McDougal, L. K., C. D. Steward, G. E. Killgore, J. M. Chaitram, S. K. McAllister, and F. C. Tenover. 2003. Pulsed-field gel electrophoresis typing of oxacillin-resistant Staphylococcus aureus isolates from the United States: Establishing a national database. J. Clin. Microbiol. 41:5113-5120.

Meira, Q. G. S., I. M. Barbosa, A. J. A. Athayde, J. P. Siqueira-Júnior, and E. L. Souza. 2012. Influence of temperature and surface kind on biofilm formation by Staphylococcus aureus from food-contact surfaces and sensitivity to sanitizers. Food Contr. 25:469-475.

Melchior, M. B., M. H. Van Osch, T. J. Lam, J. C. Vernooij, W. Gaastra, and J. Fink-Gremmels. 2011. Extended biofilm susceptibility assay for Staphylococcus aureus bovine mastitis isolates: Evidence for association between genetic makeup and biofilm susceptibility. J. Dairy Sci. 94:5926-5937.

Oliveira, R., J. Azeredo, and P. Teixeira. 2003. The importance of physicochemical properties in biofilm formation and activity. Pages 211-231 in Biofilms in Wastewater Treatment: An Interdisciplinary Approach. S. Wuertz, P. L. Bishop, and P. A. Wilderer, ed. IWA, London, UK.

Pagedar, A., J. Singh, and V. K. Batish. 2010. Surface hydrophobicity, nutritional contents affect Staphylococcus aureus biofilms and temperature influences its survival in preformed biofilms. J. Basic Microbiol. 50:S98-S106.

Shanks, R. M. Q., N. P. Donegan, M. L. Graber, S. E. Buckingham, M. E. Zegans, A. L. Cheung, and G. A. O'Toole. 2005. Heparin stimulates Staphylococcus aureus biofilm formation. Infect. Immun. 73:4596-4606.

Simões, M., L. C. Simões, and M. J. Vieira. 2010. A review of current and emergent biofilm control strategies. Lebenson. Wiss. Technol. 43:573-583.

Sousa, C., P. Teixeira, and R. Oliveira. 2009. Influence of surface properties on the adhesion of Staphylococcus epidermidis to acrylic and silicone. Int. J. Biomater. 2009:718017.

Stepanović, S., D. Vuković, I. Dakić, B. Savić, and M. Švabic-Vlahović. 2000. A modified microtiter-plate test for quantification of staphylococcal biofilm formation. J. Microbiol. Methods 40:175-179.

Szweda, P., M. Schielmann, S. Milewski, A. Frankowska, and A. Jakubczak. 2012. Biofilm production and presence of $i c a$ and bap genes in Staphylococcus aureus strains isolated from cows with mastitis in the eastern Poland. Pol. J. Microbiol. 61:65-69.

Vasudevan, P., M. K. Nair, T. Annamalai, and K. S. Venkitanarayanan. 2003. Phenotypic and genotypic characterization of bovine mastitis isolates of Staphylococcus aureus for biofilm formation. Vet. Microbiol. 92:179-185.

Zadoks, R. N., W. B. Van Leeuwen, D. Kreft, L. K. Fox, H. W. Barkema, Y. H. Schukken, and A. Van Belkum. 2002. Comparison of Staphylococcus aureus isolates from bovine and human skin, milking equipment, and bovine milk by phage typing, pulsed-field gel electrophoresis, and binary typing. J. Clin. Microbiol. 40:38943902 . 